\title{
Palliative care in primary health care: scoping review
}

\author{
Eveline Treméa Justino $0^{1,2}$ \\ (D) https://orcid.org/0000-0002-3141-835X \\ Maristel Kasper ${ }^{3,4}$ \\ (D) https://orcid.org/0000-0003-3978-0342 \\ Karen da Silva Santos 3,5 \\ (1D) https://orcid.org/0000-0001-5829-5882 \\ Rita de Cassia Quaglio ${ }^{6}$ \\ (iD) https://orcid.org/0000-0002-4522-1881 \\ Cinira Magali Fortuna ${ }^{3}$ \\ (D) https://orcid.org/0000-0003-2808-6806
}

1 Universidade Estadual do Oeste do Paraná, Curso de Enfermagem, Foz do Iguaçu, PR, Brazil.

2 Scholarship holder at the Fundação Araucária, Foz do Iguaçu, PR, Brazil.

3 Universidade de São Paulo, Escola de Enfermagem de Ribeirão Preto, PAHO/WHO Collaborating Centre at the Nursing Research Development, Ribeirão Preto, SP, Brazil.

${ }^{4}$ Scholarship holder at the Coordenação de Aperfeiçoamento de Pessoal de Nível Superior (CAPES), Brazil.

5 Scholarship holder at the Fundação de Amparo à Pesquisa do Estado de São Paulo (FAPESP), Brazil.

${ }^{6}$ Universidade de São Paulo, Hospital da Clinicas da Faculdade de Medicina de Ribeirão Preto, Equipe Gestora de Neurologia e Equipe de Interconsulta de Cuidados Paliativos, Ribeirão Preto, SP, Brazil
Objective: to map the available evidence on the main topics investigated in palliative care in primary health care. Method: scoping review type study carried out in five databases, including original articles, based on the descriptors palliative care, palliative care at the end of life, terminal care, terminal state, primary health care and their respective acronyms and synonyms, totaling 18 publications. The extraction of data from primary studies was performed using an instrument produced by the authors and which allowed the construction of the categories presented. Results: 18 publications were included in this review. Among the most studied themes are the difficulties of the teams regarding the continuity of care in the health network; the importance of in-service education by the multidisciplinary team; professional unpreparedness; bioethics; the validation and application of scales for prognosis and care for some pathologies such as cancer and diabetes; among others. Conclusion: it became evident that palliative care in primary health care has been gradually developed, but it is necessary to consider the organization of primary health care and the social policies that support or weaken it, being considered a complex challenge.

Descriptors: Palliative Care; Terminal Care; Hospice Care; Critical Illness; Primary Health Care; Review.

\section{How to cite this article}

Justino ET, Kasper M, Santos KS, Quaglio RC, Fortuna CM. Palliative care in primary health care: scoping review. Rev. Latino-Am. Enfermagem. 2020;28:e3324. [Access _- + - - ] Available in: DOI: http://dx.doi.org/10.1590/1518-8345.3858.3324.month day year 


\section{Introduction}

The most recent definition of Palliative Care (PC) was published in 2018 and developed after a large project involving more than 400 members from 88 countries of the International Association for Hospice \& Palliative Care (IAHPC), an association that maintains close ties and official relations with the World Health Organization $(\mathrm{WHO})^{(1)}$. Currently, PCs are defined as "active holistic care, offered to people of all ages who are in intense suffering related to their health, resulting from serious illness, especially those who are at the end of life. The objective of Palliative Care is, therefore, to improve the quality of life of patients, their families and their caregivers"(1).

Thus, offering palliative care to people with serious illnesses takes into account not only the person, but everyone involved in the care. As a definition, serious illness is understood as "any acute or chronic illness and/ or condition that causes a significant disability and that can lead to a condition of disability and/or weakness for a long period, or even death"(2).

In Brazil, isolated discussions and initiatives in PC have been found since the 1970s. It is noteworthy, however, that it was in the 1990s that the first organized services began to appear(3). It is noteworthy that, in the 1980s, the life expectancy of Brazilians was 62.5 years $^{(4)}$. Currently, the reality is different, the numbers have increased, both life expectancy has risen to 76 years $^{(4)}$ and the number of services that provide palliative care in the country. This increase in life expectancy is the result of investments in public policies by the State, including the implantation and implementation of the Unified Health System (UHS).

Until August 2018, after a survey carried out by the National Academy of Palliative Care (NAPC), 177 palliative care services were identified, distributed in the five regions of Brazil. Of these, 58\% (103 services) are concentrated in the Southeast region, 20\% (36 services), in the Northeast region, 14\% (25 services), in the South region, $5 \%$ (eight services), in the Midwest region, while only $3 \%$ (five services) are located in the North of the country(5).

As a result of the growth in the life expectancy of the population, there is an increase in the occurrence of Chronic-degenerative Noncommunicable Diseases (CNCDs), which make the demand for PC a contemporary public health problem. An integrative review(6) on primary health care (PHC) and PC, held in 2014, aimed to understand the roles of PHC professionals in palliative care and pointed out that $\mathrm{PHC}$ can make a difference to patients and their families by having easy access to them, close to home, be able to carry out constant management of symptoms and sensitivity to the realities of the community: "Professionals monitor the aging and fragility of their patients, the efforts of families to accommodate the new care needs of their members, fears, financial insecurity and, therefore, cannot avoid this moment: it is exactly in situations like this that the full potential of PHC actions and the Family Health Strategy (FHS) becomes more evident. No other health service can stand side by side with these families with such property and face the path of palliation with constant presence, guidance and welcome"(6).

A systematic review (7), held in 2015 on palliative care and PHC, aimed to identify, in the view of health professionals, the ethical problems arising from practice in this context. The ethical problems detected were the scarcity of resources, the lack of knowledge about PC, the lack of communication skills, the difficulty of establishing limits in the clinical relationship, the work overload and the lack of support from the reference services. The authors concluded that, in order to incorporate PCs in PHC, specific norms and training are required, in addition to the culture of shared and coresponsible care $^{(7)}$.

Therefore, in order to know the current panorama of palliative care in $\mathrm{PHC}$ and because there are no studies like this, which synthesize scientific evidence in relation to the theme, justifying this study and its importance, it is presented as an objective: to map the available evidence on the main topics investigated in palliative care in primary health care.

\section{Method}

This is a scoping review study, carried out based on a set of techniques in order to map knowledge on certain topics in a research field. It differs from systematic review because it aims to focus on broader themes and include studies with different designs ${ }^{(8)}$. The elaboration of the scoping review followed a process consisting of five stages: a) Identifying the research questions; b) Identify the relevant studies valid for the investigation; c) Selection of review studies; d) Mapping of data from studies included in the review; e) Confront, summarize and report the results ${ }^{(8)}$.

For this, the PICO strategy was used, acronym for Patient, Intervention, Comparison and Outcomes, for the definition of the following guiding question: "What evidence is available about palliative care in primary health care?". For the construction of the aforementioned 
question and to carry out the search, the PICO strategy was stipulated as: P for Population, Patient or Problem (what evidence is available); I of Interest (palliative care) and Context CO (primary health care).

This review was conducted in the databases Medical Literature Analyzes and Retrieval System Online (PubMed/MEDLINE), Latin American and Caribbean Literature in Health Sciences (LILACS), Web of Science, Scopus and Cumulative Index to Nursing \& Allied Health Literature (CINAHL). For this, the controlled and indexed descriptors were used for each of the databases in this review. For the combination of these, the boolean operators OR and AND were used.

From the research question, terms were selected in the Health Sciences Descriptors (DeCS) and terms in the Medical Subject Headings (MeSH) containing the appropriate descriptors for searching the databases. The controlled descriptors used were as follows: a) PubMed/ MEDLINE: palliative care (synonym: palliative treatment), hospice care (synonym: hospice program), terminal care, critical illness, primary health care (MeSH); b) LILACS: palliative care (synonyms: palliative care, palliative treatment), palliative care at the end of life (synonyms: terminally ill care, palliative care for terminally ill patients, comfort care, intermittent care program, palliative care program), terminal assistance (synonym: terminal care), terminal care (synonym: terminal illness), Primary Health Care (synonyms: primary care, primary care in health, primary health care, basic care, basic health care, basic care in health, basic care, primary care, primary health care, primary care, primary health care and primary health care (DeCS); c) Web of Science; d) Scopus; e) CINAHL: Palliative care (synonym: palliative treatment), hospice care (synonym: hospice program), terminal care, critical illness, primary health care (MeSH).

For the selection of studies, the following inclusion criteria were considered: a) original research articles; b) made available in the full version; c) published in the period 2009 to 2019, the last ten years; d) Portuguese, French, Spanish and English languages.

Exclusion criteria were defined: a) studies whose theme palliative care is presented as a "recommendation" in the results and conclusions, not being configured as a central object of the study; b) dissertations, theses, public policies and videos. The search for jobs for primary research took place on April 27, 2019 via advanced form.
After identification, primary studies were selected, according to the guiding question and the previously defined inclusion and exclusion criteria. This step was carried out by two reviewers independently. The instrument, designed for the purpose of extracting and analyzing data from the included studies, was composed of the following items: 1- article identification; 2object and/or question and/or objectives of the study; 3- type of study/design; 4- data production tools and/ or techniques; 5- year; 6- magazine; 7- participants and/or sample; 8- main results; 9- area; 10- country. The stages of selection of the studies included the identification, screening, eligibility and inclusion.

The categorization was the form adopted for the analysis of the results in which it was extracted how the PC has been carried out in the PHC. The work of analyzing the studies consisted of a careful task. There was an interest in knowing and characterizing the panorama of the studies according to its investigated object. For the presentation of the data, we chose to build sequential figures that sought to demonstrate how the CP theme in PHC was studied by different authors.

\section{Results}

In the research, a total of 154 studies were found, 25 in LILACS, 112 in Web of Science, five in PubMed/ MEDLINE, three in CINAHL, one in Scopus and three were identified by manual search. After proceeding with the inclusion and exclusion criteria, two successive evaluations and disregarding duplicate articles, 18 publications $^{(9-26)}$ were relevant for this review, since they met the study question and pre-established criteria, as explained in the analysis flowchart (Figure 1).

With regard to language, eleven studies analyzed were published in Portuguese ${ }^{(9-11,18-21,23-26)}$ and from Brazilian authors, five were published in Spanish $^{(12-13,15-17)}$ and three in English ${ }^{(14,16,22)}$. Of the included studies, eight ${ }^{(9-11,17-21)}$ used the qualitative approach and ten, the quantitative(12-16,22-26). As for the instruments / techniques for data collection/production, questionnaires, interviews, observation, discussion groups and application of scales were used. Among the study participants, the following were identified: health professionals; formal and informal caregivers; patients eligible for palliative care. Two studies, also, had sample of medical records of patients, according to Figure 2. 


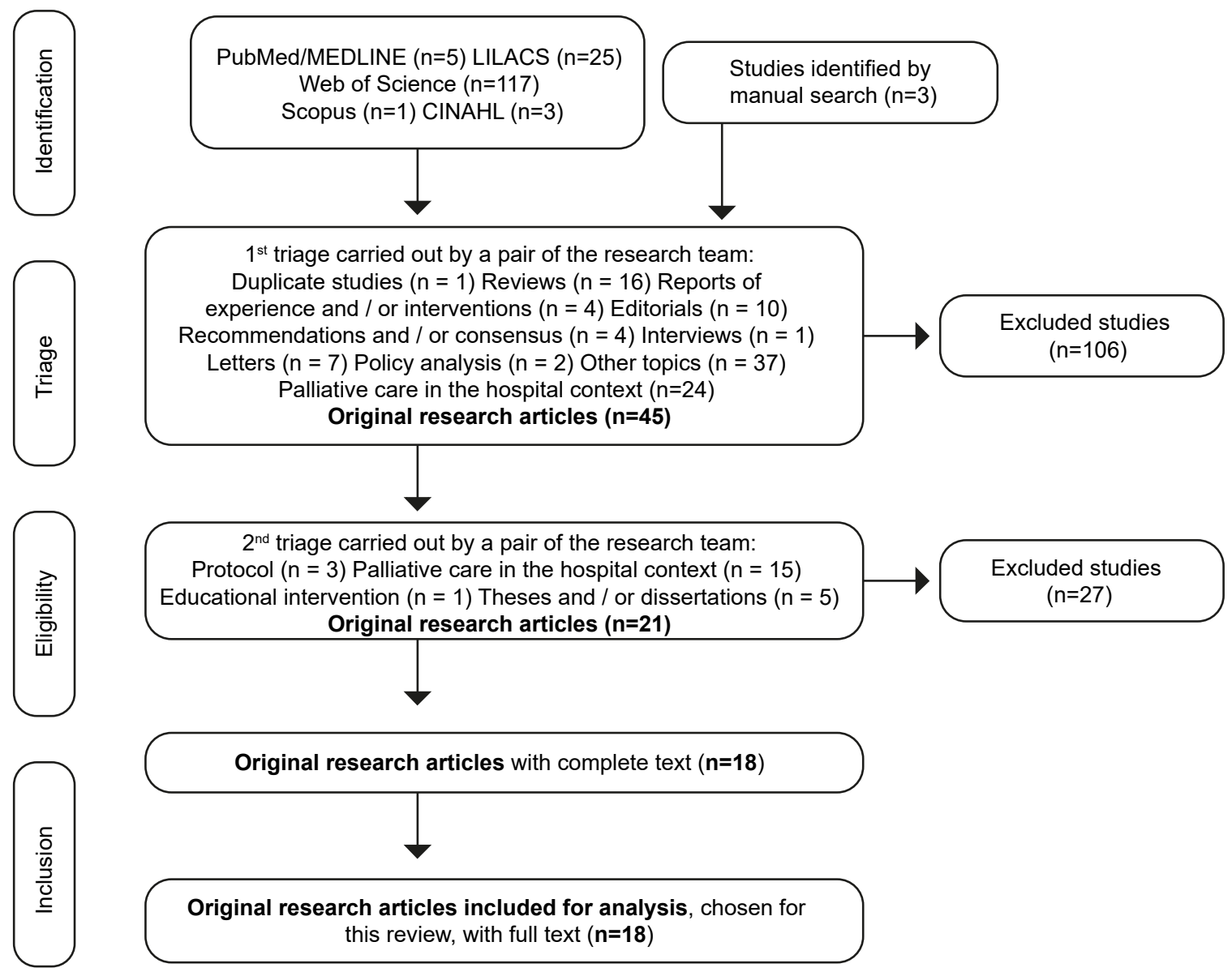

Figure 1 - Flowchart of the study selection process for the review of the adapted scope of the Preferred Reporting Items for Systematic Review and Meta-Analyses (PRISMA). Ribeirão Preto, SP, Brazil, 2019

\begin{tabular}{|c|c|c|c|}
\hline Article & Journal/Country & Study design & Participants and/orsample \\
\hline $\begin{array}{l}\text { Being cared for by a relative: existential feelings of } \\
\text { cancer patients }^{(9)}\end{array}$ & \multirow{3}{*}{$\begin{array}{l}\text { Texto \& Contexto } \\
\text { - Enfermagem / } \\
\text { Brazil }\end{array}$} & $\begin{array}{l}\text { - Qualitative } \\
\text { - Interviews }\end{array}$ & 20 patients \\
\hline $\begin{array}{l}\text { Meaning of being a caregiver of a family member } \\
\text { with cancer and dependents: contributions to } \\
\text { palliation }^{(10)}\end{array}$ & & $\begin{array}{l}\text { - Qualitative } \\
\text { - Interviews }\end{array}$ & 17 family caregivers \\
\hline $\begin{array}{l}\text { Meanings attributed by health professionals to } \\
\text { palliative care in the context of primary care }{ }^{(11)}\end{array}$ & & $\begin{array}{l}\text { - Qualitative } \\
\text { - Interviews }\end{array}$ & $\begin{array}{l}25 \text { professionals from health units } \\
\text { and the Family Health Support Center } \\
\qquad\left(\text { FHSC }^{*}\right)\end{array}$ \\
\hline $\begin{array}{l}\text { Diagnosis of tumor asthenia in Primary Care. } \\
\text { Proposal of correlation between of the scales }{ }^{(12)}\end{array}$ & \multirow{2}{*}{$\begin{array}{c}\text { Medicina } \\
\text { Paliativa / Spain }\end{array}$} & $\begin{array}{c}\text { - Observational, descriptive study } \\
\text { - Computerized clinical history } \\
{\left.\text { (DIRAYA }{ }^{\dagger}\right) \text { during consultations and }}_{\text {home visits }} \\
\text { home }\end{array}$ & 67 patients \\
\hline $\begin{array}{l}\text { Validation of a prognostic model of survival based } \\
\text { on biological parameters for terminal cancer } \\
\text { patients cared for at home }{ }^{(13)}\end{array}$ & & $\begin{array}{c}\text { - Quantitative } \\
\text { - Analytical, observational and } \\
\text { prospective study } \\
\text { - Clinical history from home visit }\end{array}$ & 80 patients \\
\hline $\begin{array}{l}\text { Identification and characteristics of patients with } \\
\text { palliative care needs in Brazilian primary care }{ }^{(14)}\end{array}$ & $\begin{array}{l}\text { BMC Palliative } \\
\text { Care/Australia }\end{array}$ & $\begin{array}{l}\text { - Quantitative } \\
\text { - Cross-sectional study } \\
\text { - Questionaire }\end{array}$ & 238 patients \\
\hline $\begin{array}{l}\text { Prevalence of pain as a reason for consultation } \\
\text { and its influence on sleep: experience in a primary } \\
\text { care center }{ }^{(15)}\end{array}$ & $\begin{array}{c}\text { Atención } \\
\text { Primaria/ Spain }\end{array}$ & $\begin{array}{l}\text { - Cross-sectional description } \\
\text { - Questionaire } \\
\text { - Pain scale application } \\
\text { - Clinical interview }\end{array}$ & 206 patients \\
\hline $\begin{array}{l}\text { A new measure of home care patients' dignity } \\
\text { at the end of life: The Palliative Patients' Dignity } \\
\text { Scale (PPDS })^{(16)}\end{array}$ & $\begin{array}{c}\text { Palliative and } \\
\text { Supportive Care/ } \\
\text { Spain }\end{array}$ & $\begin{array}{l}\text { - Quantitative } \\
\text { - Questionaire }\end{array}$ & $\begin{array}{c}80 \text { participants, including patients, family } \\
\text { caregivers and professionals }\end{array}$ \\
\hline $\begin{array}{l}\text { Sick people at the end of life: experiences in the } \\
\text { accessibility to social health resources }\end{array}$ & $\begin{array}{c}\text { Enfermería } \\
\text { Universitaria / } \\
\text { Spain }\end{array}$ & $\begin{array}{l}\text { - Qualitative } \\
\text { - Discussion grups } \\
\text { - Interviews }\end{array}$ & 41 caregivers \\
\hline $\begin{array}{l}\text { (In defense of) Palliative Care in Primary Health } \\
\text { Care }{ }^{(18)}\end{array}$ & $\begin{array}{l}\text { O Mundo da } \\
\text { Saúde / Brazil }\end{array}$ & $\begin{array}{l}\text { - Qualitative } \\
\text { - Interviews }\end{array}$ & $\begin{array}{l}11 \text { health professionals linked to the } \\
\text { Family Health Strategy }\left(\mathrm{FHS}^{\ddagger}\right)\end{array}$ \\
\hline
\end{tabular}

(the Figure 2 continue in the next page...) 


\begin{tabular}{|c|c|c|c|}
\hline $\begin{array}{l}\text { Perception of family members and health } \\
\text { professionals about end-of-life care in the context } \\
\text { of primary health care }{ }^{(19)}\end{array}$ & $\begin{array}{l}\text { Ciência \& Saúde } \\
\text { Coletiva / Brazil }\end{array}$ & $\begin{array}{l}\text { - Qualitative } \\
\text { - Interviews }\end{array}$ & $\begin{array}{l}\text { Seven family members; three FHS } \\
\text { professionals }{ }^{\ddagger} ; \\
\text { two professionals from the Home Care } \\
\text { Program }\end{array}$ \\
\hline $\begin{array}{l}\text { Palliative care in home care: the perspective of } \\
\text { occupational therapists }^{(20)}\end{array}$ & $\begin{array}{c}\text { Cadernos } \\
\text { de Terapia } \\
\text { Ocupacional / } \\
\text { Brazil }\end{array}$ & $\begin{array}{l}\text { - Qualitative } \\
\text { - Interviews }\end{array}$ & Eight occupational therapists \\
\hline $\begin{array}{l}\text { Palliative care in primary health care: ethical } \\
\text { considerations }^{(21)}\end{array}$ & $\begin{array}{c}\text { Revista Bioética } \\
\text { / Brazil }\end{array}$ & $\begin{array}{c}\text { - Qualitative } \\
\text { - Case study } \\
\text { - Interviews } \\
\text { - Analysis of medical records } \\
\text { - Home visit } \\
\end{array}$ & $\begin{array}{l}\text { Seven FHS teams } \\
\text { Two patients in palliative care }\end{array}$ \\
\hline $\begin{array}{l}\text { New demands for primary health care in Brazil: } \\
\text { palliative care } \\
\text { (22) }\end{array}$ & $\begin{array}{l}\text { Investigación y } \\
\text { educación en } \\
\text { enfermería / } \\
\text { Colombia } \\
\end{array}$ & $\begin{array}{c}\text { - Quantitative } \\
\text { - Descriptive } \\
\text { - Application of the Karnofsky } \\
\text { Performance Scale (KPS§) } \\
\end{array}$ & 160 medical records \\
\hline $\begin{array}{l}\text { Comfort of formal and informal caregivers of } \\
\text { patients in palliative care in primary health care }\end{array}$ & $\begin{array}{l}\text { Revista Rene/ } \\
\text { Brazil }\end{array}$ & $\begin{array}{l}\text { - Quantitative } \\
\text { - Cross-sectional study } \\
\text { - Questionaire }\end{array}$ & $\begin{array}{l}50 \text { caregivers of patients in palliative } \\
\text { care }\end{array}$ \\
\hline $\begin{array}{l}\text { Perspectives for palliative care in primary health } \\
\text { care: a descriptive study }{ }^{(24)}\end{array}$ & $\begin{array}{l}\text { Online Brazil } \\
\text { Journal of } \\
\text { Nursing/Brazil }\end{array}$ & $\begin{array}{c}\text { - Documental } \\
\text { - Descriptive } \\
\text { - Application of KPS§ }\end{array}$ & 2715 medical records \\
\hline $\begin{array}{l}\text { Interface between social support, quality of life and } \\
\text { depression in users eligible for palliative care }{ }^{(25)}\end{array}$ & $\begin{array}{c}\text { Revista da } \\
\text { Escola de } \\
\text { Enfermagem da } \\
\text { USP /Brazil }\end{array}$ & $\begin{array}{c}\text { - Quantitative } \\
\text { - Cross-sectional } \\
\text { Correlational } \\
\text { - Interviews } \\
\text { - Application of KPS§ }\end{array}$ & 687 patients \\
\hline $\begin{array}{l}\text { Identifying patients for palliative care in primary } \\
\text { care in Brazil: experience of the Being at Your Side } \\
\text { Project }{ }^{(26)}\end{array}$ & $\begin{array}{c}\text { Revista Brasileira } \\
\text { de Medicina } \\
\text { de Familia e } \\
\text { Comunidade / } \\
\text { Brazil }\end{array}$ & $\begin{array}{c}\text { - Quantitative } \\
\text { - Application of Supportive and } \\
\text { Palliative Care Indicators Tool } \\
\left.\text { (SPICT }{ }^{* *}\right)\end{array}$ & 38 patients \\
\hline
\end{tabular}

${ }^{*}$ FHSC = Family Health Support Center; ${ }^{+}$DIRAYA = Computerized clinical history; ${ }^{\ddagger}$ FHT = Family Health Teams; ${ }^{\text {}}$ KPS = Karnofsky Performance Scale; ${ }^{\uparrow}$ PPDS $=$ Palliative Patients' Dignity Scale; ${ }^{*}$ SPICT $=$ Supportive and Palliative Care Indicators Tool.

Figure 2 - Summary of articles with authors, magazines and countries, type of study, instruments and/or techniques for data production, participants and/or sample of articles analyzed. Ribeirão Preto, SP, Brazil, 2019

The context of the studies was variable. Several experiences were found, such as: in daily life and patient care at home ${ }^{(9,19)}$; meaning of being a caregiver and on $\mathrm{PC}^{(10,11)}$ for health professionals; evaluation of tumor asthenia(12); validation and application of a tool for prognosis ${ }^{(13)}$; identification and characterization of patients in PC and services ${ }^{(14,22,24,26)}$; pain evaluation ${ }^{(15)}$; assessment of dignity at the end of life ${ }^{(16)}$; difficulties in accessing $\mathrm{PCs}^{(17)}$; the work process in $\mathrm{PHC}^{(18)}$; perspectives of occupational therapists in $P C$ in $\mathrm{PHC}^{(20)}$; ethical problems(21); comfort of caregivers of patients in $\mathrm{PC}^{(23)}$; relationship between social support, quality of life and depression in PC patients in $\mathrm{PHC}^{(25)}$ (Figure 3).

\begin{tabular}{|c|c|}
\hline tives & $\mathrm{Ma}$ \\
\hline $\begin{array}{l}\text { Understand the daily life of cancer patients in } \\
\text { palliative care when experiencing the care of their } \\
\text { family at home }{ }^{(9)} \text {. }\end{array}$ & $\begin{array}{l}\text { Patients who received authentic care from their families reflect the impact they had, even in the } \\
\text { face of the mishaps that have grown and transcended. Home care, combined with palliative care, is } \\
\text { capable of giving "wings" to those who viewed their lives as threatened. }\end{array}$ \\
\hline $\begin{array}{l}\text { Understand the meaning of being a caregiver } \\
\text { for a family member with cancer and with high } \\
\text { dependence for daily activities }{ }^{(10)} \text {. }\end{array}$ & $\begin{array}{l}\text { It meant, for the caregiver, to be terrified with the diagnosis, with the t } \\
\text { and being-with-the-other in the disease. He showed himself to be bus } \\
\text { and helpful. Palliative care must permeate the nurse's work so that it i }\end{array}$ \\
\hline $\begin{array}{l}\text { Understar } \\
\text { professior } \\
\text { Primary } \mathrm{H}\end{array}$ & $\begin{array}{l}\text { The professionals recognized the need for the othe } \\
\text { meanings involved the need for a system organize } \\
\text { with the curative hospital-centered model and the i }\end{array}$ \\
\hline $\begin{array}{l}\text { sthenia in Primary Care, } \\
\text { sibilities and its gradation with two } \\
\text { s, the adapted ICD*-10 (ICD*-10) } \\
\text { nd the graduated Karnosfky index }\end{array}$ & $\begin{array}{l}\text { The study confirmed the existence of a negative correlation or inverse relatio } \\
\text { degrees of tumor asthenia, according to the diagnostic criteria of ICD*-10, for } \\
\text { against IK'. Easy and accessible tool in any care environment, including prim } \\
\text { care, not only a functional indicator, but can also assess and grade tumor ast }\end{array}$ \\
\hline $\begin{array}{l}\text { To verify the } \\
\text { pronounced } \\
\text { with biologic } \\
\text { home }{ }^{(13)} \text {. }\end{array}$ & $\begin{array}{l}\text { ses is of } \\
\text { aspects }\end{array}$ \\
\hline $\begin{array}{l}\text { Identify how many patients in the Brazilian } \mathrm{FHS}^{\ddagger} \\
\text { program have needs for PC } \mathrm{PC}^{\S} \text { Describe the } \\
\text { health conditions and sociodemographic status } \\
\text { of patients in the } \mathrm{FHS}^{\ddagger} \text { program with } \mathrm{PC}^{\S} \text { needs; } \\
\text { Describe the professional and social support } \\
\text { received by patients in the } \mathrm{FHS}^{\ddagger} \text { program with } \\
\mathrm{PC} \text { needs }^{(14)} \text {. }\end{array}$ & 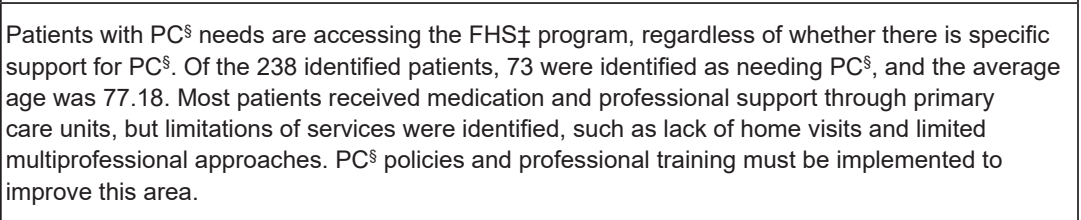 \\
\hline
\end{tabular}


Determine the frequency of pain as a reason for visiting in a primary care consultation and knowing your influence ${ }^{(15)}$.

Develop a new and brief instrument to be employed in dignity measurement, one based on the perceptions of patients, relatives, and professionals about dignity ${ }^{(16)}$

Identify the main limitations and difficulties in accessing socio-health resources that people have lived at the end of life, through the experiences and perceptions of the caregivers of these patients ${ }^{(17)}$

Analyze the work process of health professionals who work in Family Health / Primary Care and have already taken care of people in the process of dying in order to outline possible contributions to the area of Public Health with regard to the implementation of palliative care in Attention Primary ${ }^{(18)}$

Reflect on the care of people with terminal illnesses in Primary Health Care $\left(\mathrm{PHC}^{* *}\right)^{(19)}$.

To know and reflect on the perspectives of occupational therapists in relation to implementation of palliative care in home care ${ }^{(20)}$

Identify cases of users in order to inventory the ethical problems that the team experiences ${ }^{(21)}$.

Assess the need for incorporation of palliative care in primary health care through the characterization of users eligible for this type of care, enrolled in a program for devices dispensing ${ }^{(22)}$

Analyze the comfort of formal and informal caregivers of patients in palliative care, identifying the variables associated with difficulties in home care $^{(23)}$

Identify patients eligible for palliative care and characterize the services involved in Primary Health Care ${ }^{(24)}$

To analyze the relationship between social support, quality of life and depression in patients eligible for palliative care seen at $\mathrm{PHC}^{* *}$ in a municipality in the interior of Minas Gerais Brazil $^{(25)}$.

To present the process of identification of palliative care patients in a Family Health Strategy's team in Brazil ${ }^{(26)}$.

${ }^{*} \mathrm{ICD}=$ International Classification of Diseases; ${ }^{+} \mathrm{KI}=$ Karnofsky Index; ${ }^{*} \mathrm{FHS}=$ Family Health Teams; ${ }^{\text {SPC }}=$ Palliative Care; 口VAS = Visual Analysis Scale; "PPDS $=$ Palliative Patients' Dignity Scale $;{ }^{* *} \mathrm{PHC}=$ Primary Health Care $;{ }^{+\dagger} \mathrm{KPS}=$ Karnofsky Performance Scale

Figure 3 - Synthesis with object and/or question and/or objectives of the studies and main results found in the analyzed articles. Ribeirão Preto, SP, Brazil, 2019

\section{Discussion}

The analysis of scientific production has shown that, although there have been advances in recent years, palliative care practices in $\mathrm{PHC}$ have still been incipient and, when they occur, present limits, as described in the results in figure 3 , as discontinuity of care ${ }^{(13,21)}$, the complexity and/or difficulties in palliative care at home ${ }^{(19-}$ 20,23), the peculiarities of palliative care with high cost demands - infrastructure ${ }^{(20)}$, the insufficient number of visits by health professionals ${ }^{(14)}$, limited multidisciplinary approaches ${ }^{(14)}$, insufficient professional training(14,20-21), the reduced scientific production in the area(21), the need to structure $\mathrm{PHC}$ for this purpose ${ }^{(24)}$, the existence of very general care protocols ${ }^{(17)}$ and difficulties in accessing psychological support(17).

Such aspects are related to the organization of care networks and primary health care. In Brazil, Family Health teams represented advances in access and health indicators, but face difficulties of various kinds, such as economics, with underfunding of health, training of professionals and improvement of network articulation, among others ${ }^{(27)}$.

An analysis of the current panorama of the PC, carried out in 2018, indicated that, although aware that primary care may be the strategy with the lowest cost and greatest impact on the health of a population, the hospitals ${ }^{(5)}$. Perhaps, the incipience of this practice in provision of palliative care in the country is centered on 
Brazilian services is demonstrated by the absence of a public health policy that specifically structures or guides the development of these actions ${ }^{(5)}$.

A study involving Brazil and France addressed the transition of patients between hospital palliative care services and homes and showed that, in both countries, there are difficulties in this transition related, among others, to caregiver fatigue and fear of death. In this study, hospital discharge was also addressed with rationalizing purposes such as the release of beds(28).

The studies ${ }^{(14,20-21)}$ addressed the insufficient training of professionals for palliative care and this theme was also evidenced in research ${ }^{(7)}$, pointing out that the professionals' unpreparedness to deal with the demands and needs of chronic health conditions was present in countries that have an aging population longer than Brazil.

Death, understood as a theme that is part of the daily life of health services, integrates the different phases of the human life cycle, but it is still a topic that is treated in a reduced way, both in the training of health professionals and in health services, compromising the principle of integrality.

In the study(11) it was shown that the request by family members not to reveal the diagnosis to the patient may coincide with the professional's option, reinforcing their own difficulties with the subject. An integrative review of PC in PHC highlighted that the monitoring of the process of death and grief and the communication of bad news, among other topics, are rarely addressed in training and health services ${ }^{(7)}$.

In some speeches of the professionals and in their actions, the curative model still prevails, focused on the disease and the specificity of care. The training of professionals could favor health education for patients and families, especially in relation to the implementation of $\mathrm{PC}$ in $\mathrm{PHC}^{(11,14)}$.

In addition, Permanent Health Education (PHE) is considered learning at work, takes everyday life as an open space and a permanent reviewer of professional practices, as a place of subjectivity and discussions ${ }^{(29)}$. Thus, it is believed that institutionalized spaces that can put professional practices in an interdisciplinary way, are essential for the promotion of comprehensive palliative care.

However, it is considered that the provision of palliative care in primary care is related not only to the professionals' capacity for the development of palliative care, but also with universal health systems that are organized in a network and guided by an expanded conception of the health-disease process, taking into account social determinants and social inequalities. "Poor" teams in poor locations that materialize selective primary care are unable to take on the complexity of primary health care and palliative care.

Teams without adequate working conditions may, for example, make an insufficient number of visits by health professionals to these families ${ }^{(14)}$.

A study ${ }^{(30)}$ on Primary Health Care in Latin America addressed 12 countries and discussed the relationship between the implementation of comprehensive primary care and universal social protection. Certainly, this aspect does not match the implementation of neoliberal policies and flexibility of social rights, as has been seen not only in Brazil.

The authors addressed Primary Health Care in full, which considers the family and community focus, the territorial base, the work in multi-professional teams and social participation and the expansion of this aspect in Latin America in left and center-left governments. Concerns were raised about the current political scenario in this region of the world.

It was observed that five $(9-10,12-13,23)$ articles brought the association of palliative care and cancer. Another five ${ }^{(16,22,24-26)}$ articles mentioned cancer, but not in isolation, they also pointed out other diseases such as diabetes, Alzheimer's disease, as well as respiratory and cardiovascular diseases. The expansion of PCs to other diseases appeared in a study on human rabies and suggested a review of clinical guidelines, proposing the introduction of PCs for people with rabies in endemic countries ${ }^{(31)}$.

Initially, palliative practice was directed only to cancer patients, but gradually it started to be incorporated by other specialties involved in the care of patients with chronic-degenerative diseases. In its first edition, published in 1995, the "Medical guidelines of the National Palliative Care Organization (NPCO) for determining the prognosis in Selected Non-Cancerous Diseases" determined the prognosis of non-cancer diseases and included them in the palliative care programs. The first non-cancer diseases to be included were: Congestive Heart Failure ( $\mathrm{CHF}$ ), Chronic Obstructive Pulmonary Disease (COPD) and Alzheimer's disease ${ }^{(32)}$.

Subsequently, the second edition, published in 1996, added the following pathologies: Aids (Acquired Immunodeficiency Syndrome); liver and kidney disease; leakage; coma and Amyotrophic Lateral Sclerosis (ALS) ${ }^{(32)}$.

If the association of diseases with palliative care can facilitate the specificity of the care to be offered, for Primary Health Care teams, other knowledge needs to be mobilized, such as, for example, the dynamics of family relationships and the production of unique therapeutic projects, as pointed out in a study ${ }^{(18)}$. 
The use of scales/instruments to define people eligible for palliative care was addressed in six articles, using the Palliative Performance Scale (PPS) ${ }^{(10)}$ and the Karnofsky Performance Scale (KPS)(14,22,24-26). Another article proposed the correlation between two scales, the KPS and the ICD-10 classification (ICD-10) $)^{(12)}$.

In addition to the scales to identify people's eligibility for palliative care, other instruments, such as the Visual Analog Scale (VAS), were used to assess pain intensity(15), the General Comfort Questionnaire (GCQ), to assess the comfort of formal and informal caregivers( $^{(23)}$, the European Cancer Research and Treatment Organization scale (EORTC QLQ-C15PAL), to measure patients' quality of life, the Medical Outcome Study (MOS) scale, for assessing the level of social support, and the Center for Epidemiological Studies - Depression (CES-D) scale for identifying symptoms of depression(25).

An article that aimed to develop the Dignity Scale for Palliative Patients (PPDS) and used six other scales is highlighted: the Patient Dignity Inventory (PDI), which identifies sources of suffering in patients at the end of life; the Hospital Anxiety and Depression Scale (HADS); the Brief Resilient Coping Scale (BRCS), which measures resilience; the GES Questionnaire, referring to spirituality; the IBPC C-30 Quality of Life scale (EORTCQLQ-C30) and the Duke-UNC-11 Functional Social Support Questionnaire, which assesses confidential and affective social support ${ }^{(16)}$.

In addition, it is essential that the primary health care professional knows and knows how to use the main scales used in palliative care, such as the Edmonton Symptom Assessment Scale, the Karnofsky Performance Scale and the Palliative Performance Scale. Thus, professionals can have tools to help guide the specific care plan for palliative care.

Regarding the work process of FHS professionals involved in the care of patients at the end of the process of living, the following ways of caring can be identified: compassion-empathy ${ }^{(9-10,18-19)}$; respect and willingness to understand the meaning attributed by the patient and their family about death ${ }^{(10,17,21)}$; communication used as a strategy to establish a bond(9-10,18-19,21,24); active and sensitive listening(9-10,18,21); non-judgment or abandonment of the patient and maintenance of hope $^{(10,19)}$, even about the efficiency of the treatment for symptom relief. This demonstrates that the way of doing, at this moment, emphasizes the ethical and interpersonal dimensions in the professional-patientfamily relationship ${ }^{(18)}$.

The discussion on bioethics was not a recurring theme in the selected articles and, in only two ${ }^{(18,21)}$ publications, this subject was addressed. In one of ${ }^{(21)}$ them, ethics in palliative care was the central theme, including aspects involving the communication of bad news, such as lack of sincerity and hiding the truth. Another article(18) approached the subject, presenting a brief discussion about otherness, considered one of the references of bioethics.

It should be added that, for the effectiveness and guarantee of palliative care in primary care, it is assumed that there is articulation between the various health services and several other sectors - consequently, other professional categories - such as: transport, to ensure accessibility; social security, guaranteeing social rights; and justice, to ensure access and equity.

In addition, in the intra-sectoral prism of the health system, relations with the various medical specialties (Geriatrics, Neurology, Psychiatry, Cardiology) must be signed and perpetuated, in addition to different multi-professional categories, areas of epidemiological information and management, among others ${ }^{(33)}$.

The importance of the multi-professional team was mentioned as fundamental in five ${ }^{(11,14,19-21)}$ articles, with an emphasis on the need for theoretical, scientific knowledge and specific clinical skills in the domain of different professions so that the integrality of actions in the process of offering palliative care takes place, thus contemplating the physical, psychosocial and spiritual dimensions of the patient and their family.

In addition, within its scope, PHC has the potential to develop a set of interventions that favor the quality of life and continuity of palliative care, inside and outside the home, and can potentially favor and provide the patient with care close to the patient family and friends, in addition to reducing the risk of infections and suffering from unnecessary hospitalizations ${ }^{(11,34)}$.

In addition, for the PC to evolve in $\mathrm{PHC}$, it is necessary to plan the offer, identify and meet the needs, the available resources, practice the sharing of information through appropriate communication and define the commitments of the parties involved. This is done in collaborative relationships and practices between different professionals, families and managers.

In line with Resolution No. 41, of October 31, 2018, which provides for guidelines for the organization of palliative care, in the light of integrated continuous care, within the scope of the Unified Health System (UHS), it is advised that "the palliative care should be part of the integrated continuous care offered within the scope of the Health Care Network (HCN)", with PHC being considered the originator of care and territorial action ${ }^{(33)}$.

In order for changes to occur in the scope of management and care, the ability to dialogue and problematize the current concepts within each health team is essential. The construction of new pacts, with 
the approximation of concepts about comprehensive, humanized and quality care, in addition to equity and milestones that occurred strongly in the process of reforming the Brazilian health system, are essential for such changes to occur(29).

This study has as its limit the non-problematization of the different health systems where the studies were produced, and primary health care is not always developed in its integral aspect, and there is still a strong orientation of health services according to the hospital logic. In addition, another limitation is the inclusion of articles in only four languages (Portuguese, French, Spanish and English), which may have limited access to other publications on the topic.

It is hoped that the compilation of the findings presented in this review may give rise to new lines of research and encourage other publications, contributing to the scientific advancement of the theme and performing the function of aid and support for the restructuring of practices and policies related to palliative care in primary health care.

\section{Conclusion}

The evidence and themes investigated relating palliative care in primary health care point to the possibility of this care, since these teams work closely with families and the territories where they live. Such a process could occur in health systems that implement primary care articulated with social policies, which ensure health as a human right, being difficult to implement in non-universal systems and with primary care teams with few resources and poor articulation in a service network.

The studies point out possibilities of using scales that can assist in the identification and follow-up of people in palliative care, such as the Edmonton Symptom Assessment Scale, the Karnofsky Performance Scale and the Palliative Performance Scale. There are also productions that point out aspects of subjectivity as important, highlighting empathy, listening and valuing cultural aspects.

There are articles that deal with specific pathologies, with emphasis on cancer, diabetes and several pathologies that participate in the epidemiological and demographic transition. It is emphasized that specific care needs to be recognized at the same time that, in primary health care, other knowledge needs to be mobilized to consider family and social dynamics and thus build unique therapeutic projects.

It was possible to identify, in this review, that there is a concern with the initial training of health professionals and on-the-job training, as this is still incipient. To improve this situation, the insertion of the PC discipline in health courses is recommended and the implementation of permanent education and health education actions to bring family members and professionals closer together, taking into account cultural and social aspects of each family and team.

However, it is reaffirmed that the provision of palliative care in primary care is a complex challenge that goes beyond the preparation of professionals and family members, involves changing the logic and the care model that is still centered on diseases, economic logic and professional practices that compete with each other in a corporate way. This process is also related to social policies that conflict with the implementation of neoliberal policies and the flexibilization of social rights.

\section{References}

1. International Association for Hospice Palliative Care. Global Consensus-based palliative care definition. [Internet]. Houston, TX: The International Association for Hospice and Palliative Care; 2018 [cited May 05, 2019]. Available from: https://hospicecare.com/ what-we-do/projects/consensus-based-definition-ofpalliative-care/definition/

2. Kelley AS. Defining "Serious Illness". J Palliat Med. [Internet]. 2014 [cited May 10, 2019];17(9):985. Available from: https://www.liebertpub.com/doi/ pdf/10.1089/jpm.2014.0164

3. Cuidados Paliativos no Brasil. [Internet]. São Paulo: Instituto Paliar; 2019. [Acesso 5 mai 2019]. Disponível em: https://www.paliar.com.br/cuidados-paliativos

4. Instituto Brasileiro de Geografia e Estatística. Tábua completa de mortalidade para o Brasil - 2017: Breve análise da evolução da mortalidade no Brasil. [Internet]. 2018 [Acesso 5 mai 2019]. Disponive em: https:// www.ibge.gov.br/estatisticas/sociais/populacao/9126tabuas-completas-de-mortalidade. $h$ tml? =\&t=resultados 5. Academia Nacional de Cuidados Paliativos. Panorama dos Cuidados Paliativos no Brasil. [Internet]. 2018 [Acesso 5 mai 2019]. Disponívem em: https://paliativo. org.br/wp-content/uploads/2018/10/Panorama-dosCuidados-Paliativos-no-Brasil-2018.pdf

6. Silva MLSR. The role of Primary Health Care professionals in palliative care. Rev Bras Med Fam Comunidade. [Internet]. 2014 [cited May 7, 2019];9(30):45-53. Available from: https://www.rbmfc. org.br/rbmfc/article/view/718

7. Saito DYT, Zoboli ELCP. Palliative care and primary health care: scoping review. Rev Bioét. [Internet]. 2015 [cited May 7, 2019];23(3):593-607. Available from: http://www.scielo.br/scielo.php?script=sci_arttext\&pid $=$ S1983-80422015000300593 
8. Levac D, Colquhoun $\mathrm{H}, \mathrm{O}^{\prime}$ Brien, KK. Scoping studies: advancing the methodology. Implementation Sci. [Internet]. 2010 [cited May 7, 2019];5(1):19. Available from: https://implementationscience.biomedcentral. com/articles/10.1186/1748-5908-5-69

9. Wakiuchi J, Salimena AMO, Sales CA. Being cared by a family member: the existential feelings of cancer patients. Texto Contexto Enferm. [Internet]. 2015 [cited May 7, 2019];24(2):381-9. Available from: http://www.scielo.br/scielo.php?script=sci_arttext\&pid =S0104-07072015000200381

10. Marchi JA, Paula CC, Girardon-Perlini NMO, Sales CA. The meaning of being a caregiver of a dependent relative suffering from cancer: palliative contributions. Texto Contexto Enferm. [Internet]. 2016 [cited May 5, 2019];25(1):e0760014. Available from: http://www.scielo.br/scielo.php?pid=S010407072016000100311\&script=sci_abstract\&tIng=en

11. Carvalho GAL, Menezes RMP, Enders BC, Teixeira GA, Dantas DNA, Oliveira DRC. Meanings attributed to palliative care by health professional in the primary care context. Texto Contexto Enferm. [Internet]. 2018 [cited May 7, 2019];27(2):e5740016. Available from: http://www.scielo.br/scielo.php?pid=S010407072018000200320\&script=sci_arttext

12. Cruz LFC, Estévez MJM, Turiño-Luquec JD. Diagnóstico de la astenia tumoral en Atención Primaria. Propuesta de correlación entre dos escalas. Med Paliat. [Internet]. 2012 [Acceso may 2019];19(1):24-30. Disponible en: http://dx.doi.org/10.1016/j.medipa. 2010.09.002

13. López AR. Validación de un modelo pronóstico de supervivencia basado en parámetros biológicos para pacientes con cáncer terminal atendidos en ámbito domiciliario. Med Paliat. [Internet]. 2013 [Acceso 5 may 2019];20(1):3-9. Disponible en: http://dx.doi. org/10.1016/j.medipa.2012.01.012

14. Marcucci FCI. Identification and characteristics of patients with palliative care needs in Brazilian primary care. BMC Palliat Care. [Internet]. 2016 [cited May 10, 2019];15(51):1-10. Available from: http://dx.doi. org/10.1186/s12904-016-0125-4

15. Calsina-Berna A, Millán NM, González-Barboteo J, Díaz LS, Sales JP. Prevalencia de dolor como motivo de consulta y su influencia en el sueño: experiencia en un centro de atención primaria. Aten Primaria. [Internet]. 2011 [Acceso 7 may 2019];43(11):568-76. Disponible en: http://dx.doi.org/10.1016/j.aprim.2010.09.006

16. Rudilla D, Oliver A, Galiana L, Barreto P. A new measure of home care patients' dignity at the end of life: the palliative patients'dignity scale (PPDS). Palliat Support Care. [Internet]. 2016 [cited May 05,
2019];14:99-108. Available from: http://dx.doi. org/10.1017/S1478951515000747

17. Ruiz-Fernandéz MD, Ortega-Galán AM, CabreraTroya J, Ibáñez-Masero O, Carmona-Rega MI, RelinqueMedina $F$, et al. Personas enfermas al final de la vida: vivencias en la accesibilidad a recursos sociosanitarios. Enfermería Universitaria. [Internet]. 2017 [cited May 07, 2019];14(1):10-8. Available from: http://dx.doi. org/10.1016/j.reu.2016.11.004

18. Combinato DS, Martins STF. (Pleading for) palliative care in primary health care. Mundo Saúde. [Internet]. 2018 [cited May 05, 2019];36(3):433-44. Available from: http://bvsms.saude.gov.br/bvs/artigos/mundo_saude/ defesa_cuidados_paliativos_atencao_primaria.pdf

19. Queiroz AHAB, Pontes RJS, Souza AMA, Rodrigues TB. Perception of family members and health professionals on end of life care within the scope of primary health care. Ciênc Saúde Coletiva. [Internet]. 2013 [cited May 07, 2019];18(9):2615-23. Available from: http:// dx.doi.org/10.1590/S1413-81232013000900016

20. Portela SG, Galheigo SM. Palliative care in home care: perceptions of ocupational therapists. Cad Ter Ocup. [Internet]. 2015 [cited May 07, 2019];23(1):15-29. Available from: https://www.researchgate.net/ publication/307842167_Palliative_care_in_home_care_ perceptions_of_occupational_therapists

21. Souza HL, Zoboli ELCP, Paz CRP, Schveitzer MC, Hohl $K G$, Pessalacia JDR. Palliative care in primary health care: ethical considerations. Rev Bioét. [Internet]. 2015 [cited May 07, 2019];23(2):349-59. Available from: http://dx.doi.org/10.1590/1983-80422015232074

22. Paz CRP, Pessalacia JDR, Zoboli ELCP, Souza HL, Granja GF, Schveitzer MC. New demands for primary health care in Brazil: palliative care. Invest Educ Enferm. [Internet]. 2016 [cited May 05, 2019];34(1):46-57. Available from: http://dx.doi.org/10.17533/udea.iee.v34n1a06

23. Meneguin S, Ribeiro R, Ferreira MLSM. Conforto de cuidadores formais e informais de pacientes em cuidados paliativos na atenção primária à saúde. Rev Rene. [Internet]. 2016 [Acesso 10 mai 2019];17(6):797803. Disponível em: http://dx.doi.org/10.15253/21756783.2016000600010

24. Azevedo C, Rates CMP, Pessalacia JDR, Mata LRF. Perspectivas para os cuidados paliativos na atenção primária à saúde: estudo descritivo. Online Braz J Nurs. [Internet]. 2016 [Acesso mai 2019];15(4):683-93. Disponível em: http://dx.doi.org/10.17665/16764285.20165370

25. Azevedo C, Pessalacia JDR, Mata LRF, Zoboli ELCP, Pereira MG. Interface between social support, quality of life and depression in users eligible for palliative care. Rev Esc Enferm USP. [Internet]. 2017 [cited May 7, 
2019];28(51):e03245. Available from: http://dx.doi. org/10.1590/S1980-220X2016038003245

26. Corrêa SR, Mazuko C, Mitchell G, Pastrana T, Lima $L$, Murray SA. Identifying patients for palliative care in primary care in Brazil: Project Estar ao Seu Lado's experience. Rev Bras Med Fam Comunidade. [Internet]. 2017 [cited May 7, 2019];12(39):1-8. Available from: http://dx.doi.org/10.5712/rbmfc12(39)1507

27. Macinko J, Mendonça CS. The Family Health Strategy, a strong model of Primary Health Care that delivers results. Saúde Debate. [Internet]. 2018 [cited Feb 7, 2020];42(Sp. Iss.):18-37. Available from: https://doi. org/10.1590/0103-11042018s102

28. Cordeiro FR, Kruse MHL, Carlin N. La sortie d'unités de soins palliatifs au Brésil et en France: expériences de patients atteints d'un cancer avancé et de leurs familles. Médecine Palliative [Internet]. 2018 [Accès 7 Fev 2020];17(3):139-147. Disponible en: https://doi. org/10.1016/j.medpal.2018.03.002

29. Ceccim RB. Permanent Education in the Healthcare field: an ambitious and necessary challenge. Interface. [Internet]. 2005 [cited May 5, 2019];9(16):161-77. Available from: http://dx.doi.org/10.1590/S14143283200500010001

30. Giovanella L, Almeida PF. Comprehensive primary care and segmented health systems in South America. Cad Saúde Pública. [Internet]. 2017 [cited Feb 5, 2020];33(Suppl. 2):e00118816. Available from: https://doi.org/10.1590/0102-311×00118816.

31. Tarantola A, Crabol Y, Mahendra JB, In S, Barennes $\mathrm{H}$, Bourhy $\mathrm{H}$, et al. Caring for patients with rabies in developing countries - the neglected importance of palliative care. Trop Med Int Health. [Internet]. 2016 [cited May 7, 2019];21(4):564-7. Available from: https:// onlinelibrary.wiley.com/doi/full/10.1111/tmi.12670

32. Stuart B. The NHO medical guidelines for non-cancer disease and local medical review policy: hospice access for patients with diseases other than cancer. Hosp $]$. [Internet]. 1999 [cited May 5, 2019];14(3):139-54. Available from: https://paliativossinfronteras.org/wpcontent/uploads/THE-NHO-MEDICAL-GUIDELINES-FORNON-CANCER-DISEASES_1.pdf

33. Mendes EC, Vasconcellos LCF. Palliative cares on cancer and the doctrinal principles of SUS.
Saúde Debate. [Internet]. 2015 [cited May 7, 2019];39(106):881-92. Available from: http:// www.scielo.br/scielo.php?script $=$ sci_arttext\&pid $=$ S0103-11042015000300881

34. Ministério da Saúde (BR). Resolução n. 41/GM/ CIT de 31 de outubro de 2018 (BR). Dispõe sobre as diretrizes para a organização dos cuidados paliativos, à luz dos cuidados continuados integrados, no âmbito Sistema Único de Saúde (SUS). [Internet]. Diário Oficial da União 23 nov 2018. [Acesso 5 mai 2019]. Disponível em: http://www.in.gov.br/web/guest/materia/-/asset_ publisher/Kujrw0TZC2Mb/content/id/51520746/ do1-2018-11-23-resolucao-n-41-de-31-de-outubrode-2018-51520710 Creative Commons (CC BY).

This license lets others distribute, remix, tweak, and build upon your work, even commercially, as long as they credit you for the original creation. This is the most accommodating of licenses offered. Recommended for maximum dissemination and use of 